\title{
SEMANTIC ISSUES OF TRANSLATING AMERICAN SOCIOCULTURAL STEREOTYPES
}

\author{
Svitlana Lyubymova, Nadezhda Tomasevich, Olena Mardarenko \\ National Polytechnic University, Odessa, Ukraine \\ elurus2006@gmail.com
}

\begin{abstract}
Devoted to problems of translations, the work presents a qualitative analysis of semantic peculiarities of sociocultural stereotypes that influence the solutions of a translator in the process of interpreting. We hypothesised that a specific social category that exists in a source culture in the form of pragmatic predispositions, namely a sociocultural stereotype, which has no equivalent notion as well as a word in translation culture and language, is a lacunar stereotype. The words denoting sociocultural stereotypes evoke numerous images, built in accordance with cultural and ethnic patterns, therefore such stereotypes are almost impossible to preserve in translation language. The work is aimed to recognise parameters of lacunarity, to determine the semantic components that frame the reference in translation, and to suggest the ways in rendering lacunar sociocultural stereotypes. The data for research material is taken from the Corpus of Contemporary American English. As it was ascertained in the course of semantic analysis of lexical units that denote sociocultural stereotypes, the lacunarity of these stereotypes for a target culture is determined by linguistic, historic, social, and cultural parameters. A lack of appropriate lexical means in the translation language inevitably leads to some losses in denotative meaning, whereas connotative meaning is not possible to render adequately because of discrepancy between axiological systems of source and receiving cultures. Decomposition of stereotype pragmatic information into figurative, historic and connotative components enables to emphasise relevant for a particular context pragmatic component. Highlighting the relevant component, with consideration for peculiarities of represented genre and context, is a solution to convey a part of the original pragmatic information. We deduced two major techniques for translation of sociocultural stereotypes: (1) interpreting the unknown for the recipient word or (2) introducing a cultural element, which is familiar to the recipient. Representation of socio-cultural stereotypes by means of another language requires rigorous analysis of pragmatic information that stereotypes code. The work outlines future prospects for research of lacunarity and strategies to eliminate lacunae in a target culture.
\end{abstract}

Keywords: sociocultural stereotype; culture specific unit; lacuna; semantic decomposition; corpus; translation strategies.

\section{Introduction}

At the time of rapid cultural globalisation and broadening communication, the exploration of national cultural stereotypes in various aspects takes on special significance. Being a cognitive construct of a definite ethnic culture, formed under the invariable influence of language, a sociocultural stereotype activates interest of various disciplines, translation studies including. A verbal unit that represents a sociocultural stereotype in discourse is a symbol for a definite national community that preserves pragmatic information about the phenomenon of a social and cultural importance. Stereotypes belong to "the set of values, attitudes and behaviours shared by a group and passed on by learning" (Davies, 2003, p. 68). As cultural specific units stereotypes are realised in symbols, heroes, rituals, and values (Hofstede et al., 2010, p. 7), which appear due to the specific perception of the world and mental organisation of reality in a definite culture. Complications in translating these culturally specific units caused the idea of their untranslatability when the translator faces texts with terms, which are as culture-bound and culture-specific as to defy translation (Fernández Guerra, 2012). However, the universality of human language as the system of coding and decoding information, argues the possibility to transmit specifically cultural codes to different languages.

Assuming that "translation is a cross-cultural communicative act which enables different cultures to interact" (Zhang, 2013, p. 1919), we admit the need to understand beliefs, attitudes, values, and the rules of the source language in order to adequately understand the source text and adequately translate it for people who have a different set of beliefs, attitudes, values, and rules (Zare-Behtash, Firoozkoohi, 2010, p. 1). Thus, interpretation of cultural specific units calls for considerate translation strategies and an adequate competence of a source culture, the knowledge of cultural specificities, and the ability to notice such items of a culture in a broader context. Mediation between cultures has to deal with differences and take into account cultural norms when translating (Blažytė, Liubinienè, 2016). Interpretation of specific cultural units is of great importance for translation studies and for the development of intercultural competence, as the culture gaps threaten with misunderstanding, and, in a broader scale, with inevitable intercultural conflicts. The task of a translator is to interpret and render culture gaps with much accuracy.

The specific fragments of national "world picture" which are intrinsic for one nation and alien to another are designated by different terms: exoticisms (Suprun, 1958), blank spots on the semantic map of language (Stepanov, 1965), lacunae (Vinay and Darbelnet, 1958; Muraviev, 1975; Sorockin, 1988), nonequivalent lexemes (Markovina, 1982), zero lexemes (Sternin,1989), limits of a culture, or identity 
markers, which resist translation (Pym, 1993), realia (Robinson, 2003), culture-specific items (Davies, 2003). Though, the most apt and widespread term is seemingly lacuna. Originating from Latin meaning "gap or loss", lacuna is the result of language-specific categorisation, which is dependent on semiotic experience of a certain ethnic community. Understanding of such a specific cultural unit is conditioned by peculiarities of language and culture in which this unit arose. Therefore, lacunae are completely or partially unintelligible for representatives of other cultures.

Researchers identify different types of lacunae: lexical, functional, cultural, and cognitive. A cognitive lacuna is conditioned by a correlation between the concept and the lexical unit, which determines a non-existent concept in any other culture. Cultural and cognitive lacunae cause cultural untranslatability, described by Catford (1965) as a situation, which emerges when certain features, functionally relevant for the source text, are completely absent in the culture of translation (p. 99). Peculiar for definite cultural community words, which denote the way of life and its manifestations are named by Newmark (1988) "cultural words". They are associated with a particular language and cannot be literally translated (Newmark 1988, p. 94-95). Newmark (1988) differentiates several categories of cultural words, among them the group denoting social customs and ideas (pp. 95-103), sociocultural stereotypes including.

The importance to interpret culture-specific concepts for cross-cultural communication has focused the attention on cultural and historical background of texts that affect translation and translation strategies in use (Bassnett, 2011). Nowadays translation is in search of comprehensive and versatile theoretical and practical framework to enrich translation with the ideas and theories from other disciplines, such as Semantics, Pragmatics, and Culture Studies.

Particular importance to the meaning that is transferred from one language to another was given by eminent scholars (Jakobson, 1959; Nida, 1964, 1969; Catford, 1965). Translation has often been defined with reference to the meaning of a text (Catford 1965, p. 35). Nida (1969) states: "Translating consists in reproducing the receptor language the closest natural equivalent of the source language message, first in terms of meaning and secondly in terms of style" (p. 12). Emphasising the priority of meaning equivalence over formal correspondence, Nida (1969) indicates that the form should be changed to preserve the content of the message (p. 5). The principles of cognitive linguistics, introduced by Nida (1969) in translation theory, concern empirical determination of meaning, deep structures transformations, pragmatic background of the utterance which is to be translated. Claiming that "words only have meaning in terms of the culture of which they are a part", Nida (2003) declares meaning to be context-dependent in historical and cultural view (p. 77).

Equivalent receptor response, named by Nida (1996) the "dynamic translation", is achieved through grammatical, lexical and cultural adaptions to produce "a high degree of equivalence of response, or the translation will have failed to accomplish its purpose" (p. 24). Intelligible translation "is not to be measured merely in terms of whether the words are understandable and the sentences grammatically constructed, but in terms of the total impact the message has on the one who receives it" (p. 22). Establishing priority of total impact, Nida (1969) draws attention to "one of the most essential, and yet often neglected, elements", i.e. the expressive factor, "for people must also feel as well as understand what is said" (p. 25). To preserve the effect of the author wanted to produce on readers, the translator needs to find ways to convey connotative meaning, even at the expense of denotative meaning alterations (Nida, 1964, p. 160).

The fundamental problem of translation concerns the parity between belonging to different cultures source and target texts, which enables one to acknowledge the fact of the dependence of target text on the source text (Basylev, 2012, p. 32). Equivalence in difference, whether cultural or purely linguistic, is a central issue of translation. The effort to eliminate the difference between a source and target culture may cause a cognitive irrelevance that occurs when cultural concepts or notions introduced by a translator seem incompatible and incongruous for a recipient of the text. Distortion of the message in way the meaning received by a reader is different from that, which the author intends, creates a semantic noise. It is caused by social and cultural differences between the sender and the recipient of the message. To overcome semantic noise is possible by means of feedback, which is a verbal or nonverbal response of the participants in the process of negotiating ideas and exchanging meanings to each other (Steinberg, 2007, pp. 49-50). The feedback of a recipient who reads translated text is not possible to observe. Therefore, solutions to semantic noise are laid upon the translator. For this purpose, the problematic for translation units undergo semantic analysis.

The aim of our work is 1) to recognise parameters that make stereotypes culturally specific and lacunar for the target culture; 2) to determine the semantic components used as a frame of reference in translation; 3 ) to consider the ways to attain adequacy in a translation of the content of sociocultural stereotypes. 


\section{Method}

In our work, we analysed the words that represent sociocultural stereotypes both in and out the context. The data for research, taken from the Corpus of Contemporary American English (Davies, 2017), underwent contextual and semantic analyses. Totally, we examined 898 cases of the usage of keywords in the corpus samples.

Our research is a qualitative study based on a semantic analysis. Following the traditions of Newmark (1988) and Nida $(1964 ; 1969 ; 2003)$, we apply a componential analysis as a relevant procedure for interpretation of sociocultural stereotypes. Semantic decomposition is applied in order to achieve the equivalence of value, which concerns the same worth or function in translation text. The value equivalence, as seen by A. Pym, is a focus on contextual signification rather than systematic meaning; it can be achieved by undertaking componential analysis, comparison and deverbalisation (i.e. comprehension and reformulation) (Pym, 2014, p. 7). Thus, the first stage in our work is to study a cultural item first in context, then in isolation, as though it were a dictionary or an encyclopaedia entry only and finally in context again (Newmark, 1988, p. 17). Semantic decomposition is supported by a quantitative analysis that determines the reference features for translation. On results of the analysis, the parameters of cultural lacunarity of the stereotypes are deduced.

Semantic analysis is the first step in dealing with complicated for interpretation units. The next step is to find the appropriate translation strategies, which are usually defined as the procedures leading to the optimal solution of a translation problem (Krings, 1986, pp. 263-275). The procedures intended to propose a metalanguage and to catalogue possible solutions in the task of translation are to improve the acquisition of translation competence, since knowing and comparing them is definitively necessary to obtain an adequate translation (Fernández Guerra, 2012, p. 5-6).

One of the numerous classifications of translation strategies which we consider rather convenient and distinctive, includes preservation, localisation, addition, omission, globalisation, transformation, and creation techniques (Davies, 2003). Preservation refers to translation using a loan word, when no close equivalent in the target culture can be found, thus the translator maintains the source text term. Addition is a technique that provides the original cultural reference, supplemented to the text by the translator. This additional information might be placed in brackets, in the endnotes, footnotes, etc., or incorporated in the translated text as part of the passage. The opposite of addition is omission that "may simply be an act of desperation by a translator who can find no adequate way of conveying the original meaning". Globalisation is the act of replacing a culture-specific unit with a more neutral or general reference. Occasionally, instead of using cultural references with neutral connotation, translators aim to "make sure that their translated texts sound as if they originated in the culture of the target language". The references, used by a translator, are known and familiar to the readers. This technique is named localisation. Transformation refers to cases where the modification of a culture-specific unit seems to go beyond globalisation or localisation and could be seen as an alteration or distortion on the background of the original text. Creation is the invention of the translator. This technique is very rare and doubtful (Davies, 2003, p. 79-84).

Translating culture-specific units is a very challenging task and the choice of certain strategies can reveal either destructive evidence of translator's activity, or the profound knowledge and skills of the mediator between source and target texts (Fernández Guerra, 2012, p. 22).

\section{Results and Discussion}

Conveyed by means of linguistic signs (Tagiuri, 1969; Moscovici, 1984; Turner, 1994; Schiherev, 1999; Krasnyh, 2002), stereotypes are maintained and changed in the language and communication. The researchers assume that stereotypes can be revealed on all levels of the language. As subjectively determined idea, a stereotype is reflected on a syntactic level of language, in forms of judgements about certain features of stereotyped objects (Quasthoff 1978, p. 28), or it can be represented by a lexical item that codifies and interprets a category of a social world (Bartmiński 1995, p. 7). The evidence of a stereotype can also be found in connotations of the word, that make a stereotype prominent as "social meaning" in a definite context (Coulmas 1981, p. 14).

Nouns, that name stereotypes, denote the clusters of descriptive and evaluative features, including those of the character, physical appearance and typical behaviour of the stereotyped groups. These nouns act as labels of social categories that codify extensive net of attributes, implications and beliefs. A word (or a group of words), connected with a stereotype, stimulates activation of the stereotype's content in a certain context, thus forming the centre of semantic and cognitive associations.

A specific social category that exists in a source culture in the form of pragmatic predispositions, namely sociocultural stereotype, which has no equivalent notion as well as a word in translation culture and 
language, is considered in our work a lacunar stereotype. The words denoting sociocultural stereotypes evoke numerous images, built in accordance to cultural and ethnic patterns, therefore such stereotypes are almost impossible to maintain in translation language. The uniqueness of such stereotypes is perceived in the process of translation or cross-cultural communication. A lack of appropriate lexical means in translation language inevitably leads to some losses in denotative meaning, whereas connotative meaning is not possible to render adequately because of discrepancy between axiological systems of source and receiving cultures. To illustrate the above mentioned we examine several cases of lacunar for Ukrainian culture stereotypes. The choice of the stereotypes for research has been determined by the purposes of major research devoted to American cultural stereotypes and stereotyping.

\section{WASP}

The sociocultural stereotype represented by the acronym (abbreviation) WASP is constituted by initial components in a phrase "White Anglo-Saxon Protestant" pronounced together as a word. The acronym WASP denotes the upper class or elite group with disproportionately affluent economic and political advantages in American society. From the American Revolution to the 1930s, the WASPs, especially those with a clear ideology of close, upper-class ties, dominated America in all social aspects, in major areas like politics, economy, and culture. Nearly all immigrants before the 1950s were assimilated under an Anglo conformity model. Since the beginning of the twentieth century, however, Progressive WASPs supported greater meritocracy and a more diverse establishment, and gradually took the lead in promoting change. Thus, the WASP establishment has experienced a retreat, as more non WASPs, especially Catholics and Jews, entered the elite group. Despite the decline, Protestant dominance, perpetuated in American institutions, still remains (Zhang, 2015, p. 692).

The referential meaning of the word WASP indicates the category of people in American society whose privileged status makes them criticised. WASPs are presidents (George Washington, Franklin Delano Roosevelt, George H.W. Bush, Lyndon B. Johnson), political leaders (Nelson Rockefeller, John Foster Dulles, John McCain), senators (Prescott Sheldon Bush, Henry Cabot Lodge), and businessmen (Averell Harriman, Phil Gramm). They are educated in elite private schools and universities, live in fashionable districts of New York, Philadelphia, and Chicago.

Used in its figurative sense, acronym WASP means a social winged insect, which has a narrow waist, a sting, and is typically yellow with black stripes. On the ground of identical spelling, a social category is compared to a very social kind of stinging predatory insects. A wasp image is a visual symbol of the stereotype, which implies the ironic and disrespectful opinion of people that achieve leading positions in the society owing to their origin, rather than diligence and self-cultivation. To receive everything from the birth, without efforts, contradicts the realisation of "American Dream", thus evoking a hostile attitude.

The total concordance (occurrence of the word) of the word WASP in the Corpus of Contemporary American English is 2259. The following table presents the outlined in our study cases.

Table 1

WASP in Corpus of Contemporary American English

\begin{tabular}{|c|c|c|c|}
\hline \multicolumn{3}{|c|}{ WASP: total 190 } \\
\hline years & quantity & attributes & features \\
\hline $2015-2017$ & 13 & & \\
lazy & 25 & \multirow{2}{*}{$\begin{array}{c}\text { conservative } \\
\text { new } \\
\text { modern } \\
\text { classic }\end{array}$} & $\begin{array}{r}\text { character }-87 \% \\
\text { appearance }-13 \%\end{array}$ \\
\hline $2005-2009$ & 23 & 23 & \\
\hline $2000-2004$ & 84 & & \\
\hline $1995-1999$ & & & \\
\hline $1990-1994$ & & & \\
\hline
\end{tabular}

As we see, though the word occurs in discourse less if to compare with the 1990s, it is still in use denoting the elite social group in American society. The word is characterised by mostly negative pragmatic meaning, which is definitely shown in the next example: 
The acronym "Wasp", from "White Anglo-Saxon Protestant", is one many Wasps dislike, as it's redundant - Anglo-Saxons are perforce white - and inexact. Elvis Presley was a white Anglo-Saxon Protestant, as is Bill Clinton, but they are not what anyone means by "Wasp". Waspiness is an overlay on human character, like the porcelain veneer that protects the biting surface of a damaged tooth. Worse, the adjective is pejorative: "Waspy" is reserved for horse-faced women, tight-assed men, penny-pinchers, and a cappella groups (Friend 2010, p. 11-12).

While the denotative meaning of the term WASP is clearly stated in the decoded by the author abbreviation and causes no difficulty in translation (translated literally as білий протестант англосаксонського походження), the connotative meaning should be conveyed in consideration of contrasting attitudes to ordinary and popular representative of the category. In this context, the WASP can be rendered in Ukrainian as обранi. The word wispiness in the extract conveys lustre that conceals imperfection of WASP, thus it can be translated as глянець/лиск. The author marks the word waspy as a pejorative appellation of the category, explicitly showing contempt and disapproval that convey pragmatic meaning of the stereotype. Adequate rendering of the word waspy comes from sarcasm manifesting disdain and disrespect to the social elite, the suggested translation for this word is eлima. In this case, we observe transposition: an adjective in a source language is represented by a noun in a translation language to communicate a stereotypic attitude of Americans toward WASPs. Adaptations in translation as the pursuit of cultural equivalence may cause semantic shifts. Defined by Catford (1965) as departure from formal correspondence (p.73), translation shifts are inevitable changes of form and meaning as we try to communicate a valid for the context pragmatic meaning of a stereotype.

\section{Valley Girl}

Another example of a lacunar stereotype of American culture is Valley Girl. Appeared in 1980s, the stereotype represents an image of a social category of young girls that belong to upper middle class, who live in a fashionable part of Los Angeles, San Fernando Valley. Seemingly beautiful girls, spoiled by parents' wealth, they spend almost all their time shopping and appearance caring (Mitchell, Reid-Walsh 2007, p. 595). The image of an affluent girl was made famous through a movie starring Deborah Foreman, entitled "Valley Girl", and the single of the same name, performed by Moon Unit Zappa. Later the term has become applicable to any American superficial girl, who cares only about social status and personal appearance. The girls use speech patterns associated with thoughtlessness. Their slang is characterised by the excess use of words such as "like, duh, rad, awesome, totally, and oh my god". The majority of features associated with valley girls can be found among young white people in certain speech settings, as for example "in peer group youth interactions"(Eckert and Mendoza-Denton 2006, p. 141). The following table presents the stereotype of Valley Girl in the analysed corpus.

Table 2

Valley Girl in Corpus of Contemporary American English

\begin{tabular}{|c|c|c|c|}
\hline \multicolumn{2}{|c|}{ Valley Girl: total 54 } \\
\hline years & quantity & attributes & features \\
\hline $2015-2017$ & 8 & $\begin{array}{c}\text { real } \\
\text { vintage } \\
\text { perfect } \\
\text { stereotypical } \\
\text { suburban } \\
\text { middle class }\end{array}$ & $\begin{array}{r}\text { character }-48 \% \\
\text { appearance }-52 \%\end{array}$ \\
\hline $2010-2014$ & 6 & 15 & \\
\hline $1995-1999$ & 10 & & \\
\hline $1990-1994$ & 9 & & \\
\hline
\end{tabular}

As shown in the table, the stereotype still exists in American culture, and on the whole, it is used with the same frequency as in time of its emergence. The surface traits prevail in the image of a Valley Girl. The pragmatic meaning of a sociocultural stereotype is emphasised in the following abstract:

The faces of the audience grew expectant, their interest heightened by her silence. Bill, her buddy, sat smiling up at her from a folding chair in the front row. She said, high and emphatic like a valley girl, "Good! Do you think Mom was right?" There was no sound but the wind, the plash of waves, the toot of a boat too far away to see. She maintained an amused face but knew the story had bombe (Corpus of Contemporary 
American English, 2017). The meaning of the stereotype Valley Girl implies the extravagant behaviour and excessive expressiveness regarded as simpleton's quality. To convey this opinion of Valley Girls a translator needs to find a compensation of this quality in translation culture. Our suggestion for translation in Ukrainian of Valley Girl in this context is схвильована простачка.

\section{Flapper}

The noun flapper represents the sociocultural stereotype of the1920s, which regained its popularity nowadays owing to the success of the musical "Chicago" and the film "The Great Gatsby". A flapper is an emancipated sportive young woman or a giddy girl of the 1920s in America, interested in music, parties and new ideas, who was considered modern and bold, because of exaggerated fashion styles and sophisticated conduct, inclination to revolt and disdain to decorum of her mother's generation (Lyubymova 2015, p. 90). The word flapper, as well as the stereotype it denotes, is lacunar for other cultures on account of deficiency in language, historic, and cultural conformity.

The deficiency of code-units is corrected by loan words, loan translations, neologisms, semantic shifts, and circumlocutions, or periphrasis (Jacobson 1959, p. 232). The variety of suggested means to solve the problem of culture gaps can be reduced to the following two main strategies: (1) interpreting unknown for the recipient word or (2) introducing a cultural element, which is familiar for the recipient. In some cases, especially in literary translations, interpretation of lacunar stereotypes involves the risk of over translation, because "an array of linguistic signs is needed to introduce an unfamiliar word" (Jacobson 1959, p. 232). For example, the periphrasis of the word flapper is rather unwieldy. It should comprise the physical and moral aspects of the social category. The explanation of the stereotype's meaning apparently presents over translation case, which Vinay and Darbelnet defined as rendering by several units, when there is only one (Vinay, Darbelnet 1995, p. 16). To avoid over translation, compensation techniques are applied, for instance, transliteration, though intelligibility of the cultural stereotype, in this case, can be limited.

The introduction of a universal term girl, though it alludes to a familiar concept, does not convey the meaning of the stereotype as well. In the monograph, devoted to multi-aspect study of a sociocultural stereotype flapper, the classifier is used with a compensatory word flapper, i.e. a functional equivalent, expressed by a culture-neutral word girl (in Ukrainian "дівчина") comes together with English flapper, which, in terms of P. Newmark, emphasises the culture. S. Hervey and Ia. Higgins warns "the compensation exercises the translator's ingenuity, the effort it requires should not be wasted on textually unimportant features" (Hervey, Higgins 1992, p. 40).

In German multivolume dictionary, the word flapper is marked as English adoption in the meaning of "a lively girl". In major English-Ukrainian dictionaries, the word is presented in its denotative meaning with the emphasis on adolescent age. Only a few dictionaries introduce a part of the connotative meaning of the word that shows disrespect to frivolous girls (Ukrainian вертуха, легковажна жінка). A free spirit and the wish of flappers to enjoy equal with men rights is reflected in Russian translation by the word эмансипе, which in its turn is a loan from the French adjective (femme émancipé). However, manifesting the only feature of the category the word "emancipatress" does not express a pragmatic meaning of the stereotype (Lyubymova 2015, p. 36-37).

The stereotype Flapper became the symbol of the "Roaring 20s", unconcerned and prosperous period in American history, which anticipated decade of the Great Depression. The following table presents the flapper image in Contemporary American culture.

\section{Flapper in Corpus of Contemporary American English}

Table 3

\begin{tabular}{|c|c|c|c|}
\hline \multicolumn{4}{|c|}{ Flapper: total 159} \\
\hline years & quantity & attributes & features \\
\hline $2015-2017$ & 18 & \multirow{6}{*}{$\begin{array}{c}\text { style/fashion }-45 \% \\
\text { way of life }-24 \% \\
\text { allusive names }-10 \% \\
\text { historic period }-10 \% \\
\text { culture }-7 \% \\
\text { figure }-3 \% \\
\text { youth }-1 \%\end{array}$} & \multirow{6}{*}{$\begin{array}{c}\text { character }-22 \% \\
\text { appearance }-78 \%\end{array}$} \\
\hline $2010-2014$ & 23 & & \\
\hline $2005-2009$ & 42 & & \\
\hline $2000-2004$ & 24 & & \\
\hline 1995-1999 & 25 & & \\
\hline 1990-1994 & 27 & & \\
\hline
\end{tabular}


As we see in the table, stereotypical image of a flapper exists mainly in its visual form. Its popularity remains invariable due to fashion trends and the cinema based on S. Fitzgerald's novels. The extract from the novel "The Beautiful and Damned" by S. Fitzgerald (Fitzgerald 2000, p. 460) is taken for the analysis to illustrate the ways of translating the word flapper:

You will be known during your fifteen years as ragtime kid, a flapper, a jazz baby, and a baby vamp. You will dance new dances neither more nor less gracefully than you danced the old ones.

We observe the author's implicitly stated attitude to flappers, who seemed not less refined and graceful, than previous generations of women. Correlation of the word flapper with other words in the row (ragtime kid, jazz baby, baby vamp) emphasises attractiveness and popularity of young women - features prominent and primary for rendering. Meaning, as stated by R. Jakobson, is the semiotic fact that "cannot be inferred from non-linguistic knowledge of the world without assistance of the verbal code" (Jakobson 1959, p. 232). The synonymy of ragtime kid, a flapper, a jazz baby, and a baby vamp assists in translation, as the words are textually and culturally identical. Thus, as a Ukrainian translation, we suggest for this context is "спокусниця".

The assertion of P. Newmark to "give precedence to its connotations" (Newmark 1988, p. 16) is of a special importance for retaining the pragmatic meaning of sociocultural stereotypes. Studying synonyms that bear connotational meaning is an applicable technic to reproduce noticeable implications of the stereotype. For instance, flapper's buoyancy is represented by such words as tomboy - hoyden - romp, which can be rendered in translation with the required connotation (in Ukrainian бешкетниця, пустунка, веселуха). A. Pym wisely notices: "The pragmatic heterogeneity is an important part of translation, and transcultural relations in general. Such solutions can be classified as transpositions, substitutions or modulations, they are of a variety and moral complexity" (Pym 2014, p. 8).

\section{Hipster}

Being spread out by mass media, a cultural transplant hipster is not fully understood by Ukrainians, so it remains a lacunar stereotype for the Ukrainian culture. In the source language, the word hipster denotes an upper-middle-class representative of a youth subculture, who is keen on fashion, modern art, alternative rock, and supports progressive ideas. Someone who is up to date, informed and poised. The word hipster sometimes produces mockery of silly, pretentious slaves of fashion with whom the word is associated. Typically progressive in politics, hipsters in the newest time-frame are often retro and anti-tech, renouncing the latest high-style fashions and gadgets. The moniker dates back to the 1940s when jazz was the "hip" music to listen (PC Magazine Tech Encyclopaedia, 2018). The table 4 presents the concordance of the word hipster in the analysed Corpus of Contemporary American English.

\section{Hipster in Corpus of Contemporary American English}

Table 4

\begin{tabular}{|c|c|c|c|}
\hline \multicolumn{3}{|c|}{ Hipster: total 495 } \\
\hline years & quantity & attributes & features \\
\hline $2015-2017$ & 139 & lifestyle \\
travel & store \\
$2010-2014$ & 142 & neighbourhood & character $-7 \%$ \\
\hline $2005-2009$ & 99 & culture & \\
\hline $2000-2004$ & 55 & & \\
\hline $1995-1999$ & 39 & 21 &
\end{tabular}

As shown in the table, the stereotype's popularity is growing. Its qualities affect various spheres of American life claiming to be global. Interpreting this stereotype, a translator should dwell on relevant context characteristics. This requires the analysis, aimed to detach a component common to source and translation language "to exclude the culture and highlight the message" (Newmark 1988, p. 95-96). Thus, the usage of a loan word "хіпстер" (Ukrainian) in translation cannot convey the sense of the message:

"Where do you live in the city?"

"Lower East Side."

"That's appropriately hipsterish."

"Am I a hipster now too?"

"Hailey, come here."It was my mother's voice from the other side of the room. 
"I haven't decided yet." (https://corpus.byu.edu/coca). In this case, the word hipster intends to show a middle class affiliation of the personage. The translation of the word hipster in this context should enable the reader to identify the referent that lives in the area of modern art galleries and fashionable boutiques; a personage, who is bohemian and arty. There is no corresponding word in Ukrainian; therefore pragmatic information of the word hipster cannot be expressed in Ukrainian. Reasoning from a lacunar character of the word hipster for the Ukrainian culture, the word in this context can be translated as богемний буржуа, while the translation for hipsterish can be богемний.

In the following example, a physical characteristic of the stereotype is emphasised: The suffering is over. It's time, it really is time, to dance. We booked the DJ, a hipster with slicked back hair and black cigarette pants tapered to elfish, pointy-toed shoes. He'd do it for the payment of cake. (https://corpus.byu.edu/coca). The translation should deliver to the reader refinement of the style and appearance, i.e. hipster can be rendered as a fashion addict, who follows the latest fashion trends (модник, Ukrainian).

Representing adequately lacunar sociocultural stereotypes, a translator should find an appropriate descriptive or functional equivalent to avoid distortion of their meaning in the translation. The representation of absent in host culture stereotypes may be realised through different translation strategies and different kinds of solutions in each specific case. We considered some variants to eliminate lacunarity and applied them to rendering information about specific sociocultural stereotypes. As we see, indisputable solutions are rarely generated by normative principles. Following J. Catford's idea (Catford 1965, p. 27), we can state that the disclosure of lacuna in translation texts depends entirely on the competence of a translator.

\section{Conclusions}

Formed according to cultural and ethnic patterns, a socio-cultural stereotype is largely found in produced and distributed by the language community implications, which make a socio-cultural stereotype unique and lacunar for translation culture. Lacunarity of such stereotypes in the interlingual translation is determined by characteristics, which are difficult to maintain in translation. The parameters that determine lacunarity of a sociocultural stereotype in the interlingual translation are as following:

(1) linguistic, the lack of a corresponding word in lexicographic sources of translation language;

(2) social, the lack of a corresponding social group in the national stratification;

(3) historic, absence of social, economic, demographic prerequisites for such grouping;

(4) cultural, there are no allusive names and situations connected with the stereotype.

The most efficient way of translating the content of a stereotype is to find implicational equivalence, or dynamic equivalence, highlighting the relevant component of pragmatic meaning. The search of infilling semantic gap requires consideration of the context in which the original is represented. Decomposition of a stereotype meaning into figurative, extra-linguistic (or historic), and connotative components enables to emphasise relevant for a particular context pragmatic component. Another way to find implicational equivalence for a particular context is to reproduce noticeable features of a stereotype by synonyms that bear connotational meaning. Rendering a lacunar stereotype is a mode to recognise its essence and pragmatic potential conveyed by the language code of translation culture. Thus, we singled out two major techniques for translation of sociocultural stereotypes: (1) interpreting the unknown for the recipient word or (2) introducing a cultural element, which is familiar to the recipient. The work outlines future prospects for research of lacunarity and strategies to eliminate lacunae in a target culture.

\section{References:}

Bartmiński, J. (1995). Etnotsentrizm stereotipa: rezultaty issledovania nemetskih (Bohum) i pol'skih (Lublin) studentov v 1994-1994 godah [Ethnocentrism of a Stereotype: The Results of Research of German (Bochum) and Polish (Lublin) Students in 1993-1994], Rechevye I mental'nye stereotypy v sinhronii I diahronii (pp.7-9). Moscow, Russia: Institute of Slavonic and Balkan Studies of the Russian Academy of Sciences

Bazylev, V. (2012). Perevodcheskie mify [Translator's Fables]. Moscow, Russia: SGU.

Blažyte, D., \& Liubinienè, V. (2016) Culture-Specific Items (CSI) and their Translation Strategies in Martin Lindstrom Brand Sense. Studies about Languages, 29, 42-57. https://doi.org/10.5755/j01.sal.0.29.15129

Bassnett, S. (2011). Reflections on Translation. Bristol: Multilingual Matters, ix-xvi.

Catford, J. (1965). A Linguistic Theory of Translation: An Essay on Applied Linguistics. London: Oxford University Press.

Coulmas, F. (1981). Routineim Gesprach. Zurpragmatishen Fundirung der Idiomatik. Wiesbaden: Athenaion.

Davies, E. (2003). A Goblin or a Dirty Nose? The Treatment of Culture-specific References in Translations of Harry Potter. The Translator 6, 65-100. https://doi.org//10.1080/13556509.2003.10799146

Eckert, P., \& Mendoza-Denton, N. (2006) Getting Real in the Golden State (California). In W. Wolfram \& B. Ward (Eds.), American voices: How dialects differ from coast to coast (pp.139-143). Malden, MA: Blackwell.

Fitzgerald, S. (2000). The Beautiful and Damned. New York: Donnelley and Sons Company. 
Friend, T. (2010). Cheerful Money. Me, My family, and the Last Days of Wasp Splendor. Back Bay Books.

Guerra, A. F. (2012). Translating culture: problems, strategies and practical realities. A Journal of Literature, Culture and Literary Translation, 1, 1-27. https://doi.org/10.15291/sic/1.3.1t.1

Hervey, S., \& Higgins, I. (1992). Thinking Translation. London: Routledge.

Hofstede, G., Hofstede, G.J., \& Minkov, M. (2010). Cultures and Organizations: Software of the Mind: Intercultural Cooperation and its Importance for Survival. New York: McGraw Hill.

Jakobson, R. (1959). On linguistic Aspects of Translation. In R.A. Brower (Ed.), On Translation (pp.232-239). Cambridge, Massachusetts: Harvard University Press.

Krings, H.P. (1986). Translation problems and translation strategies of advanced German learners of French. In J. House S.\& BlumKulka (Eds.), Interlingual and Intercultural Communication (pp.263-275). Tubingen: Gunter Narr.

Liubymova, S. (2015). Lingvokulturny tipazh "devushka-flapper" v amerikanskom diskurse. Semantiko-kognitivnye i pragmaticheskiye aspekty reprezentatsii [Linguacultural Type "Flapper" in American Discourse. Cognitive Semantic and Pragmatic Aspects of the Representation]. Saarbrücken: Lambert Academic Publishing.

Mitchell, C.A., \& Reid-Walsh, J. (2007). Girl Culture: An Encyclopedia. Westport, Connecticut: London: Greenwood Press.

Newmark, P. (1988). A Textbook of Translation. New York: Prentice Hall.

Nida, E. (1964). Toward a Science of Translating. Leiden: E. J. Brill.

Nida, E., \& Taber Ch. (1969). The Theory and Practice of Translation. Leiden: E. J. Brill.

Nida, E. (2003). Fascinated by Languages. Amsterdam: John Benjamins.

PC Magazine Encyclopedia (2018). Retrieved 15 February, 2018 from https://www.pcmag.com/encyclopedia/term/68334/hipster

Pym, A. (2014). Exploring Translation Theories. New York: Routledge.

Robinson, D. (2003). Becoming a Translator: An Introduction to the Theory and Practice of Translation. London: Routledge.

Quastohoff, U. (1978). The Uses of Stereotype in Everyday Argument: Theoretical and Empirical Aspects. Journal of Pragmatics, 2, 1-48.

Steinberg, Sh. (2007). An Introduction to Communication Studies. Cape Town: Mills Litho.

Vinay, J.-P., \& Darbelnet J. (1995). Comparative Stylistics of French and English. A Methodology for Translation. Amsterdam and Philadelphia: John Benjamins.

Zare-Behtash, E., \& Firoozkohi, S. (2010). Culture-Specific Items in Literary Translations. Translation Journal, 14 (1). Retrieved 15 February, 2018 from https://translationjournal.net/journal/51culture.htm

Zhang, B. (2013). Innovative Thinking in Translation Studies: The Paradigm of Bassnett's and Lefevere's "Cultural Turn". Theory and Practice in Language Studies, 3 (10), 1919-1924. https://doi.org/10.4304/tpls.3.10.1919-1924

Zhang, M. (2015). WASP. In J. Stone, M.D. Rutledge, P. Rizova, A. D. Smith, X. Hou (Eds.), Wiley Blackwell Encyclopaedia of Race, Ethnicity and Nationalism. John Wiley and Sons. https://doi.org//10.1002/9781118663202.wberen692

Corpus of Contemporary American English (2017). Distributed by Mark Davies, Brigham Young University. Retrieved 15 February, 2018 from https://corpus.byu.edu/coca 